\title{
Cholesterol Side-Chain Cleavage Enzyme, Mitochondrial
}

National Cancer Institute

\section{Source}

National Cancer Institute. Cholesterol Side-Chain Cleavage Enzyme, Mitochondrial. NCI

Thesaurus. Code C40057.

Cholesterol side-chain cleavage enzyme, mitochondrial (521 aa, $\sim 60 \mathrm{kDa}$ ) is encoded by the human CYP11A1 gene. This protein plays a role in the catalysis of the side-chain cleavage reaction converting cholesterol to pregnenolone. 